\title{
Temporal Variability in Immunological Parameters: Peripheral Blood Mononuclear Cell Subsets, Serum Immunoglobulins, and Soluble Markers of Immune System Activation
}

\author{
Elizabeth M. Maloney ${ }^{1 *}$ Linda Morris Brown, ${ }^{2}$ Carole C. Kurman, ${ }^{3}$ Dietmar Fuchs, ${ }^{4}$ \\ David L. Nelson, ${ }^{3}$ Helmut Wachter, ${ }^{4}$ William A. Blattner, ${ }^{1}$ David J. Tollerud ${ }^{5}$ \\ ${ }^{1}$ Viral Epidemiology Branch, National Cancer Institute, Bethesda, Maryland \\ ${ }^{2}$ Epidemiology and Biostatistics Program, National Cancer Institute, Bethesda, Maryland \\ ${ }^{3}$ Metabolism Branch, National Cancer Institute, Bethesda, Maryland \\ ${ }^{4}$ Institut für Medizinische Chemie und Biochemie, University of Innsbruck, Innsbruck, Austria \\ ${ }^{5}$ Department of Environmental and Occupational Health, Graduate School of Public Health, University of \\ Pittsburgh, Pittsburgh, Pennsylvania
}

T-cell subsets and soluble factors of immune system activation are increasingly used as biologic markers of disease and predictors of disease progression. For example, changes in CD4 cells and CD4:CD8 ratio, sIL-2R, $B_{2} M$, neopterin, and $\lg A$ have been used in predicting AIDS onset and progression. We examined the temporal variability of T-cell subsets, monocytes, natural killer cells, B cells, immunoglobulins, soluble interleukin-2 receptor (sIL-2R), neopterin, and beta-2 microglobulin $\left(\mathrm{B}_{2} \mathrm{M}\right)$ among 135 adults tested at two time points $\sim 3$ months apart. The purpose of the study was twofold: (1) to assess the stability of these measures at two points in time, and (2) to investigate which parameters tend to track together over time, i.e., show significant longitudinal correlation. Mean population values for these immunologic parameters remained remarkably stable over the 3-month period. However, individual subjects exhibited significant temporal variability for many parameters. Unlike observations in patients with AIDS, changes in immunoglobulins and other soluble factors were not significantly correlated with changes in cellular subsets over the same period. However, change in $\mathrm{B}_{2} \mathrm{M}$ was correlated with change in neopterin $(r=.35, P \leq .0001)$, and change in $\lg A$ was correlated with changes in $\lg G$ and $\lg M(r=.44, r=.54, P \leq .001$ for both). Characterizing this temporal variability in a healthy population provides important information for researchers applying these tests in clinical and epidemiological studies. J. Clin. Lab. Anal. 11: 190-195, 1997. (c) 1997 Wiley-Liss, Inc. ${ }^{\dagger}$

Key words: T-cell subsets; soluble factors; CD4 cells

\section{INTRODUCTION: STUDYING BIOLOGICAL MARKERS}

Immunological tests, particularly T-cell subsets, are increasingly utilized to monitor the clinical status of diverse groups of patients. Epidemiologic studies of the acquired immunodeficiency syndrome (AIDS), e.g., have consistently associated T-cell subset levels, specifically CD4+ cells and the CD4:CD8 ratio, with the clinical onset of AIDS-defining illnesses among HIV-positive individuals. Recently, the Center for Disease Control and Prevention (CDC) modified the list of AIDS-defining signs and illnesses to include a CD4+T-cell proportion $<14 \%$ (1). Studies of AIDS also have identified some soluble factors of immune system activation-Immunoglobulin A (IgA), neopterin, Beta-2 microglobulin $\left(\mathrm{B}_{2} \mathrm{M}\right)$ and soluble interleukin-2 receptors (sIL-
$2 \mathrm{R}$ ) - as predictors of progression to AIDS among persons infected with HIV (2-5). Neopterin is also associated with a variety of malignancies and autoimmune diseases $(6,7)$. In other research, abnormalities of natural killer (NK) cells have been associated with chronic fatigue syndrome and cancer $(8,9)$.

With this growing body of scientific literature supporting such immunologic parameters as biologic markers of disease, information on variability of these parameters over time is critical. We have examined T-cell subsets, monocytes, natural killer cells, B cells, immunoglobulins, and soluble factors

*Correspondence to: Elizabeth M. Maloney, Viral Epidemiology Branch, National Cancer Institute, 6130 Executive Blvd., Room 434, Rockville, MD 20852.

Received 17 September 1996; Accepted 22 November 1996 
of immune system activation, specifically sIL-2R, $\mathrm{B}_{2} \mathrm{M}$, and neopterin, among a population-based, random sample of adults living in a large U.S. metropolitan area. We have previously reported results of cross-sectional associations between mononuclear cell subsets, sIL-2R, $\mathrm{B}_{2} \mathrm{M}$, neopterin, serum immunoglobulins, and demographic factors (age, sex and race) and cigarette smoking status (10-15) among a larger sample of this population. The results of these studies provided information on the normal sources of variability between individuals in levels of these parameters as well as insight into potential confounders and effect modifiers to be accounted for in analyses of these important biological markers.

In the current study, we extended this analysis by evaluating parameter measurements in blood samples obtained from the same individuals at two points in time, $\sim 3$ months apart. The variability of these measures between the two time points was assessed, as well as the interrelationships among temporal changes in cell subset levels, immunoglobulins, and soluble markers of immune activation. These analyses provide important information for researchers and clinicians who use these markers in population studies.

\section{MATERIALS AND METHODS}

\section{Study Population}

Sera and lymphocytes for this study were obtained from a bank of specimens collected during a larger population-based survey of healthy adults in the greater Washington, D.C., metropolitan area. The sampling strategy for that study has been described elsewhere (16). Briefly, random-digit dialing and a short screening questionnaire were used to select a random sample of white and black adults stratified by age, race, gender, and smoking status. Potential study participants were screened to exclude individuals with lifestyle characteristics (intravenous drug use, homosexual activity) or medical conditions (blood product transfusion since 1975, recent hospitalization, severe allergies, use of steroid medications, history of connective tissue disease, or recent pregnancy), which might affect the immunologic parameters under investigation.

The study population for the current analysis included a subset of 135 adults from whom specimens were collected at two separate clinic visits $\sim 3$ months apart (mean 2.9 months; range .9-4.7 months). Subjects included white smokers, white nonsmokers, and black nonsmokers. Black smokers were not included in the cohort due to their small sample size in the initial population-based sample (16).

\section{Serologic Analysis}

Phlebotomy was performed on the study subjects at two points in time by a nurse phlebotomist in a mobile field station as previously described (16). Blood was drawn at approximately the same time of day to minimize the influence of diurnal variation. The serum was separated by centrifuga- tion and frozen in $1.0 \mathrm{ml}$ aliquots for storage in a liquid nitrogen freezer until withdrawn for analysis of soluble immune factors, including immunoglobulins ( $\operatorname{IgA}, \operatorname{IgE}, \operatorname{IgG}, \operatorname{IgM}$ ) as well as soluble interleukin-2 receptors (sIL-2R), beta-2microglobulin $\left(\mathrm{B}_{2} \mathrm{M}\right)$, and neopterin. Serum specimens from the two collections were tested simultaneously in the same laboratory using the following specific procedures. A commercial laboratory (Metpath, Rockville, MD) performed immunoglobulin analysis of serum $\operatorname{IgA}, \operatorname{IgE}, \operatorname{IgG}$, and $\operatorname{IgM}$ by nephelometry. Serum sIL-2R concentrations were measured by a sandwich ELISA assay as previously described (15). Neopterin was measured by a commercial radioimmunoassay (neopterin RIAcid; Henning-Berlin, Berlin). Serum $\mathrm{B}_{2} \mathrm{M}$ was measured using a commercial double-antibody radioimmunoassay (Beta-2-micro RIA; Pharmacia, Uppsala, Sweden).

\section{Flow Cytometric Analysis}

Peripheral blood mononuclear cells (PBMCs) were separated from heparinized venous blood by Ficoll-Hypaque density gradient centrifugation as previously described (10) and cryopreserved for storage. Samples were stored in the vapor phase of a liquid nitrogen freezer until withdrawn for flow cytometry analysis. Samples from the two collections were tested simultaneously.

Fluorescein-conjugated monoclonal antibodies, purchased from either Ortho Diagnostics (Raritan, NJ; ORTHO), or Becton Dickinson Monoclonal Center (Mountain View, CA; $\mathrm{BD}$, were used for PBMC analysis: OKT3 (CD3+ T cells; (ORTHO), OKT4A (CD4+ helper-inducer T-cell subset; ORTHO); OKT8 (CD8+ suppressor-cytotoxic T-cell subset; ORTHO); anti-Leu 12 (CD19+ B cells; BD); anti-Leu M3 (CD14+ monocytes; BD; anti-Leu 11A (CD16+ natural killer cells; BD); anti-HLA-DR (non-polymorphic HLA-DR antigen; BD); and mouse IgG1 (clone 11-63; BD) and IgG2 (a+b) (clones 11-4.1 and MPC-11; BD) as negative control reagents. PBMC subsets were determined using a fluorescence-activated cell sorter, FACSII (BD) interfaced to a PDP 11/24 DEC computer (Digital Equipment Corp., Landover, MD), as previously described (10). We have previously demonstrated that there is no significant change in subset levels with freezing, using this protocol (17).

\section{Statistical Analysis}

All statistical analysis was conducted using the SAS statistical package (SAS, Cary, NC). Separate multivariate linear regression analyses, using PROC GLM, were used to examine cross-sectional associations between parameter values obtained at two clinic visits, and age (20-60 years old, by decades), sex, race (blacks and whites), and smoking status (current smokers and nonsmokers). Because there were no current smokers of black race in this sample, race and smoking status were analyzed in separate models restricted to nonsmokers (blacks and whites) and white race (smokers and 
nonsmokers), respectively. Variability of analyte measurements was defined as the absolute value of the difference between analyte measurements obtained from the first and follow-up samples. Univariate linear regression analyses was used to determine independent associations between analyte variability and demographic variables, as well as smoking status. Parameter values were transformed using either logtransformed or arcsine-transformed values in order to obtain normal distributions for linear regression analyses. Pearson correlation coefficients were used to measure the strength of linear relationships between changes in T-cell subsets and immunoglobulins and changes in levels of soluble factors of immune activation (sIL-2R, $\mathrm{B}_{2} \mathrm{M}$, neopterin) as well as changes between immunoglobulins and soluble factors.

\section{RESULTS}

\section{Cross-sectional Analysis}

Table 1 describes the distribution of the study sample by age, sex, race, and smoking status. There were no significant differences in age between the categories of sex, race, or smoking status $(P=.20, p=.09, P=.50$, respectively).

Linear regression analysis was used to determine the crosssectional associations between parameter measurements obtained separately at initial and follow-up blood draws and age, sex, race, and smoking status (Table 2). Previous analyses in the larger population provided a number of a priori hypotheses regarding associations we might observe in this smaller sample (10-15). The percentage of CD4+ helper T cells increased with age, whereas the proportion of CD8+ cytotoxic suppressor $\mathrm{T}$ cells decreased with age, resulting in an increase in CD4:CD8 ratio associated with older age. CD4+ $\mathrm{T}$ cells were also higher in females compared to males, and the reverse was found for $\mathrm{CD} 8+$ cells, although neither association was statistically significant due to the small number of subjects. Current smokers had increased CD4:CD8 ratios compared to nonsmokers. The proportion of B cells (CD19)

TABLE 1. Characteristics of Study Sample

\begin{tabular}{lc}
\hline Characteristic & Number \\
\hline Age (years) & \\
$20-29$ & 20 \\
$30-39$ & 24 \\
$40-49$ & 28 \\
$50-59$ & 30 \\
$60-69$ & 33 \\
Sex & \\
male & 70 \\
female & 65 \\
Race & \\
white & 97 \\
black & 38 \\
Smoking status & \\
nonsmoker & 97 \\
current smoker & 38 \\
\hline
\end{tabular}

was higher in individuals of black race. The proportion of HLA-DR+ cells increased with age and were higher in blacks compared to whites. IgG was also positively associated with black race but negatively associated with current smoking. Among the soluble markers of immune system activation, sIL-2R was lower in blacks compared to whites and higher in smokers compared to nonsmokers. $\mathrm{B}_{2} \mathrm{M}$ levels increased with age, whereas neopterin levels decreased among current smokers and among individuals of black race. These results confirm, at two points in time, the associations previously reported in the larger study population (10-15).

\section{Temporal Changes in Immunological Parameters}

For the population as a whole, most immunologic parameters exhibited relatively small changes between the initial and follow-up visits (Table 3 ). However, the range of differences between initial and follow-up values was substantial for all parameters. Stated another way, even for the most "stable" parameters, some individuals in the population exhibited dramatic changes between the two time points. The data for these "outliers" are presented graphically in Figures $1-3$.

To address the source of this variability, we calculated the absolute value of the difference between initial and followup measures for each analyte. This approach focused the analysis on the magnitude of variation between initial and follow-up visits, rather than on a population average of positive and negative changes. Univariate linear regression analysis was used to examine whether variability was significantly associated with age, race, sex, or smoking status. Because of the number of comparisons made in this analysis, a stricter significance level of $P \leq 0.01$ was selected for these comparisons. Interestingly, when the population was stratified by age (20-44 vs. 45-69), older subjects showed more variability in every parameter evaluated, although differences were not statistically significant (data not shown). The only analyte for which variability was significantly correlated with demographic characteristics was serum IgM level. Males showed significantly more variability than females, and variability increased with age $(P=.002, P=.01$, respectively).

To determine the relationship between changes in cell subset levels and contemporaneous changes in levels of immunoglobulins and soluble markers of immune activation, we computed Spearman correlation coefficients between all cellular subsets and soluble factors. Correlations were performed for the entire population, and no associations between these immunologic parameters were detected as statistically significant at this level (data not shown).

\section{Relationships Between Individual Markers of Immune Activation}

Spearman correlation coefficients were also used to examine correlations in changes among markers of immune acti- 
TABLE 2. Adjusted Mean Values for Imunologic Parameters by Age, Sex, Race, and Smoking Status at Two Time Points ${ }^{\mathrm{a}}$

\begin{tabular}{|c|c|c|c|c|c|c|c|c|c|}
\hline \multirow[b]{2}{*}{$\underline{\text { Parameter }}$} & \multirow[b]{2}{*}{ Time point } & \multicolumn{2}{|c|}{ Age } & \multicolumn{2}{|c|}{ Sex } & \multicolumn{2}{|c|}{ Race } & \multicolumn{2}{|c|}{ Smoking status } \\
\hline & & $<44$ & $\geq 45$ & $\mathrm{~F}$ & $\mathrm{M}$ & $\mathrm{W}$ & $\mathrm{B}$ & Non & Current \\
\hline \multirow[t]{2}{*}{ CD3 (\%) } & $1 \mathrm{st}$ & 76.4 & 75.8 & 77.8 & 77.4 & 76.2 & 74.9 & 76.3 & 75.9 \\
\hline & 2nd & 74.6 & 71.4 & 74.9 & $70.7 *$ & 72.9 & $77.1 *$ & 73.1 & 72.5 \\
\hline \multirow[t]{2}{*}{ CD4 (\%) } & $1 \mathrm{st}$ & 60.0 & $63.6^{*}$ & 63.1 & 60.9 & 60.3 & 60.4 & 60.4 & 63.1 \\
\hline & 2nd & 63.5 & 63.2 & 64.9 & 61.9 & 61.6 & 63.4 & 61.7 & 65.0 \\
\hline \multirow[t]{2}{*}{ CD8 $(\%)$} & $1 \mathrm{st}$ & 21.5 & $17.1^{* *}$ & 18.9 & 19.1 & 20.7 & 21.0 & 20.7 & $17.3^{* *}$ \\
\hline & $2 n d$ & 19.2 & $16.0 * *$ & 17.7 & 17.6 & 17.9 & 19.9 & 17.0 & 16.8 \\
\hline \multirow[t]{2}{*}{ CD4:CD8 } & $1 \mathrm{st}$ & 3.2 & $4.5^{* *}$ & 4.1 & 3.7 & 3.3 & 3.2 & 3.4 & 4.4 \\
\hline & 2 nd & 4.1 & $4.9 * *$ & 4.9 & 4.2 & 4.0 & 3.4 & 4.1 & $5.1 * *$ \\
\hline \multirow[t]{2}{*}{ CD14 (\%) } & $1 \mathrm{st}$ & 10.5 & 11.8 & 10.7 & 11.8 & 10.5 & 10.9 & 10.6 & 11.9 \\
\hline & 2nd & 14.5 & 14.9 & 13.7 & 15.8 & 14.3 & $10.8^{* *} *$ & 14.4 & 15.1 \\
\hline \multirow{2}{*}{ CD16 (\%) } & $1 \mathrm{st}$ & 5.5 & 5.7 & 5.2 & 6.1 & 5.9 & 5.1 & 5.9 & 5.2 \\
\hline & $2 n d$ & 4.5 & 5.1 & 4.3 & 5.8 & 5.0 & 3.9 & 5.0 & 5.1 \\
\hline \multirow[t]{2}{*}{ CD19 (\%) } & $1 \mathrm{st}$ & 10.2 & 9.9 & 9.5 & 10.6 & 10.4 & $12.9^{*}$ & 10.4 & 9.7 \\
\hline & 2nd & 9.8 & 10.4 & 9.9 & 10.4 & 9.9 & $12.2 *$ & 9.9 & 10.4 \\
\hline \multirow[t]{2}{*}{ HLA-DR (\%) } & $1 \mathrm{st}$ & 11.7 & $14.7 * *$ & 13.4 & 13.6 & 13.1 & $17.7 * *$ & 13.2 & 13.8 \\
\hline & 2nd & 10.5 & $13.9 * *$ & 12.2 & 12.6 & 12.0 & $16.4^{* *} *$ & 12.1 & 12.8 \\
\hline \multirow[t]{2}{*}{$\operatorname{IgG}^{\wedge}(\mathrm{mg} / \mathrm{dl})$} & $1 \mathrm{st}$ & 7.0 & 7.0 & 7.1 & 7.0 & 7.1 & $7.3 * *$ & 7.1 & $6.9 *$ \\
\hline & 2 nd & 7.1 & 7.1 & 7.1 & 7.1 & 7.1 & $7.4 * *$ & 7.1 & 7.0 \\
\hline \multirow[t]{2}{*}{$\operatorname{Ig} A^{\wedge}(\mathrm{mg} / \mathrm{dl})$} & $1 \mathrm{st}$ & 5.6 & 5.6 & 5.5 & 5.6 & 5.6 & 5.3 & 5.6 & 5.6 \\
\hline & 2nd & 5.6 & 5.6 & 5.5 & 5.6 & 5.6 & 5.4 & 5.6 & 5.6 \\
\hline \multirow[t]{2}{*}{$\operatorname{IgE}^{\wedge}(\mathrm{mg} / \mathrm{dl})$} & $1 \mathrm{st}$ & 3.3 & 3.7 & 3.5 & 3.6 & 3.4 & 3.2 & 3.3 & 3.7 \\
\hline & $2 n d$ & 3.3 & 3.8 & 3.7 & 3.5 & 3.4 & 3.2 & 3.4 & 3.8 \\
\hline \multirow[t]{2}{*}{$\operatorname{Ig} M^{\wedge}(\mathrm{mg} / \mathrm{dl})$} & $1 \mathrm{st}$ & 5.3 & 5.1 & 5.2 & 5.2 & 5.2 & 5.1 & 5.2 & 5.1 \\
\hline & 2 nd & 5.3 & 5.3 & 5.3 & 5.3 & 5.4 & $5.4^{*}$ & 5.4 & 5.2 \\
\hline \multirow[t]{2}{*}{ sIL-2R (U/ml) } & $1 \mathrm{st}$ & 497.2 & 656.0 & 572.9 & 519.6 & 488.5 & $419.8^{*}$ & 469.4 & $623.1 *$ \\
\hline & 2nd & 491.4 & 592.4 & 591.1 & 563.4 & 463.9 & $360.5^{*}$ & 491.9 & $662.5^{* *}$ \\
\hline \multirow[t]{2}{*}{$\mathrm{B}_{2} \mathrm{M}(\mathrm{mcg} / \mathrm{l})$} & $1 \mathrm{st}$ & 1.3 & $1.5^{* *}$ & 1.4 & 1.4 & 1.4 & 1.3 & 1.4 & 1.4 \\
\hline & 2nd & 1.3 & $1.4 * *$ & 1.3 & 1.4 & 1.3 & 1.3 & 1.4 & 1.4 \\
\hline \multirow[t]{2}{*}{ Neoterin $(\mathrm{mmol} / \mathrm{l})$} & $1 \mathrm{st}$ & 4.8 & 5.0 & 4.8 & 5.0 & 5.4 & 4.6 & 5.4 & 4.4 \\
\hline & 2nd & 5.0 & 5.2 & 5.0 & 5.2 & 5.4 & 4.9 & 5.4 & 4.8 \\
\hline
\end{tabular}

${ }^{a}$ General linear regression models were used to analyze variability to cell subsets and markers by age, sex, race and smoking status. Smoking status was examined in a model that included only individuals of white race, adjusted for age and sex. Also, the effect of race on the dependent variables was examined in a model that included only nonsmokers, adjusted for age and sex. Age was treated as a continuous variable in the model; however, adjusted mean values are presented for parameters by the dichotomous age categories as shown.

$P$ values were obtained from models based on transformed values of the dependent variables: $* P<.05 ; * * P<.01{ }^{\wedge}{ }^{*} \log$ value.
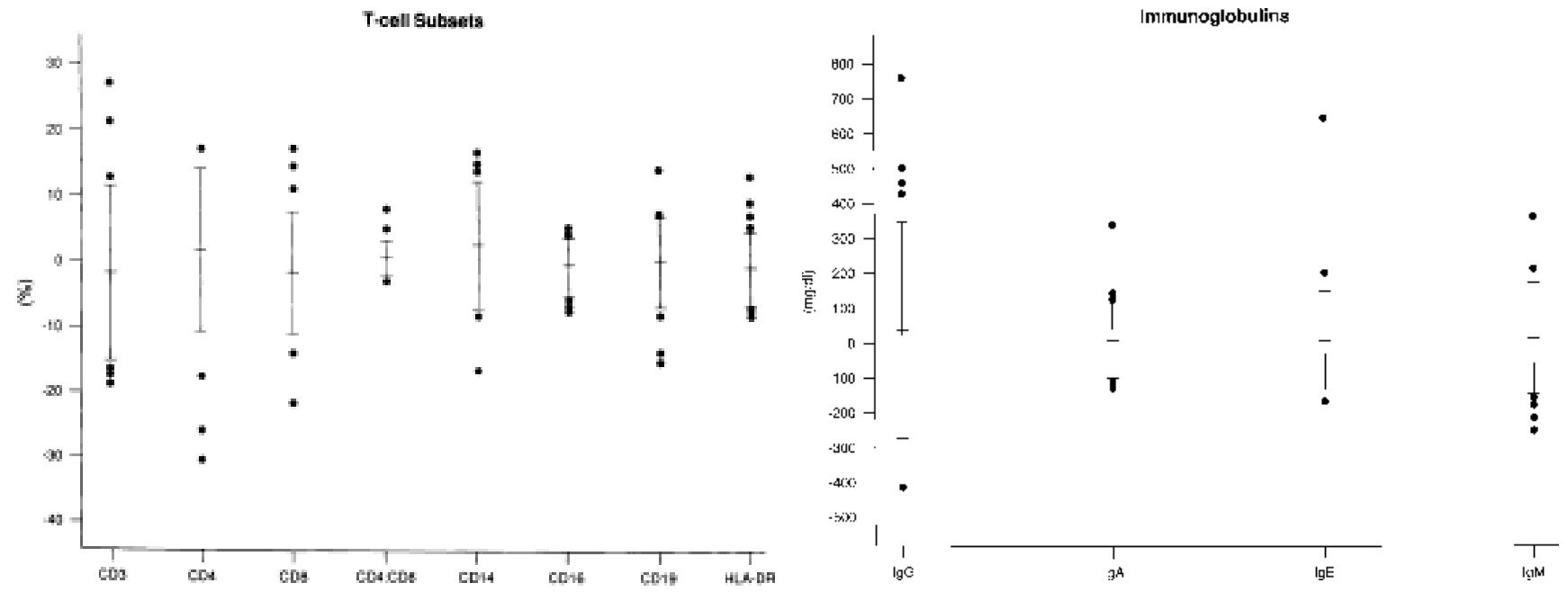

Fig. 1. Differences in T-cell subsets measured at two points in time.

Fig. 2. Differences in immunoglobulin values measured at two points in time. 


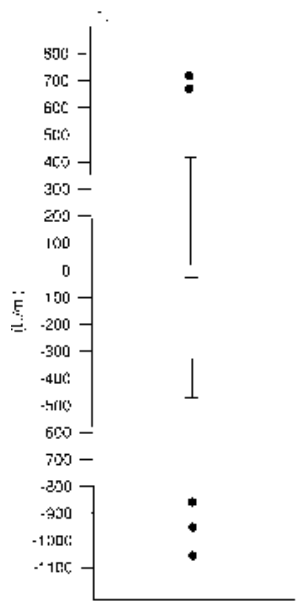

SIL-2̈
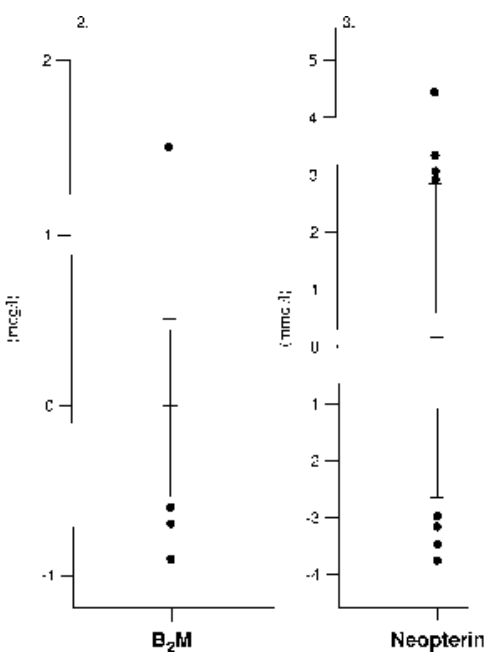

Fig. 3. Differences in soluble factors of immune activation measured at two points in time for (1) sIL-2R, (2) $\mathrm{B}_{2} \mathrm{M}$, (3) neopterin. The middle bar represents the mean difference and the upper and lower bars represent the $95 \%$ confidence interval about the mean. Points outside the bars represent outliers.

vation. Table 4 shows correlations that were statistically significant at $P \leq .001$, a critical level that takes into account the many comparisons examined. Change in SIL-2R was not correlated with any other soluble factors. Change in $\mathrm{B}_{2} \mathrm{M}$ was correlated with change in neopterin only, whereas change in neopterin was not associated with changes in any other factors. Significant associations were observed among some of the immunoglobulins (IgA, $\operatorname{IgG}, \operatorname{IgM})$.

\section{DISCUSSION}

The purpose of this investigation was to determine the degree of short-term variability in a series of immunological parameters among healthy individuals. In addition, we at- tempted to determine whether any observed variability was related to identifiable host characteristics (i.e., age, sex, race, cigarette smoking). Finally, we correlated changes in cellular subsets with changes in the level of soluble factors, as well as changes among the soluble factors themselves, to understand the relationships between these immunologic parameters in healthy subjects.

Three principal findings emerged from this analysis. First, the mean value of these parameters in a healthy population changed very little over a 3-month interval. Second, although the mean population value was relatively stable, individual subjects exhibited significant variability between the two time points. This variability was not generally related to host characteristics, such as age, sex, race, or cigarette smoking. Third, although several strong relationships were observed between changes in soluble factors between the two time points, changes in immunoglobulins and soluble markers of immune activation were not significantly correlated with changes in specific cellular subsets.

The study design and multiparameter testing protocol allowed us to explore relationships between parameters over a short time interval. It is interesting that CD4+ cells and CD4:CD8 ratio, both shown to be of value in predicting AIDS onset and progression, were not correlated with other parameters also used in AIDS research (IgA, neopterin, $\mathrm{B}_{2} \mathrm{M}$, sIL$2 \mathrm{R})$ either cross sectionally or longitudinally. This apparent discrepancy may reflect the reality that relationships between immune parameters in pathologic states do not necessarily reflect normal homeostatic relationships. Changes in neopterin were significantly correlated with changes in $\mathrm{B}_{2} \mathrm{M}$, whereas neopterin showed no temporal relationship with other soluble immune factors, including sIL-2R and immunoglobulins. These relationships mirror our earlier observation of crosssectional associations between these two parameters (13).

A significant limitation in this analysis was the inclusion

TABLE 3. Mean Values of Mononuclear Cell Subsets, Immunoglobulins, and Soluble Markers of Immune System Activation, Mean Differences Between These Two Measurements, and Range of Differences

\begin{tabular}{|c|c|c|c|c|c|}
\hline Variable & $\begin{array}{c}\text { Mean value } \\
\text { sample-1 }\end{array}$ & $\begin{array}{c}\text { Mean value } \\
\text { sample-2 }\end{array}$ & $\begin{array}{c}\text { Mean } \\
\text { difference }\end{array}$ & $\begin{array}{l}\text { Percent } \\
\text { change }\end{array}$ & $\begin{array}{l}\text { Range of } \\
\text { differences }\end{array}$ \\
\hline CD3 $(\%)$ & 75.71 & 74.00 & -1.71 & 2.3 & $(-18.30,27.40)$ \\
\hline CD4 (\%) & 61.17 & 62.96 & 1.79 & 2.9 & $(-30.50,17.40)$ \\
\hline CD8 (\%) & 19.94 & 18.31 & -1.63 & 8.2 & $(-21.20,17.20)$ \\
\hline CD4:CD8 & 3.59 & 4.17 & .58 & 16.2 & $(-2.73,8.50)$ \\
\hline CD14 (\%) & 11.07 & 13.60 & 2.53 & 23.1 & $(-16.40,17.00)$ \\
\hline CD16 (\%) & 5.57 & 4.82 & -.74 & 13.3 & $(-7.20,5.20)$ \\
\hline CD19 (\%) & 10.89 & 10.72 & -.17 & 1.6 & $(-14.90,14.50)$ \\
\hline HLA-DR $(\%)$ & 14.67 & 13.53 & -1.14 & 7.8 & $(-7.90,13.40)$ \\
\hline $\operatorname{IgG}(\mathrm{mg} / \mathrm{dl})$ & 1291.17 & 1328.95 & 37.78 & 2.9 & $(-410.00,760.00)$ \\
\hline $\operatorname{IgA}(\mathrm{mg} / \mathrm{dl})$ & 281.94 & 290.05 & 8.11 & 2.9 & $(-122.00,342.00)$ \\
\hline $\operatorname{IgE}(\mathrm{mg} / \mathrm{dl})$ & 57.16 & 66.55 & 9.38 & 16.4 & $(-163.30,645,90)$ \\
\hline $\operatorname{IgM}(\mathrm{mg} / \mathrm{dl})$ & 205.80 & 223.12 & 17.31 & 8.4 & $(-243.00,368.00)$ \\
\hline sIL-2R (U/ml) & 506.74 & 470.90 & -35.83 & 7.1 & $(-1061.00,706.00)$ \\
\hline $\mathrm{B} 2 \mathrm{M}(\mathrm{mcg} / \mathrm{l})$ & 1.36 & 1.33 & -.03 & 2.2 & $(-.90,1.50)$ \\
\hline Neopterin $(\mathrm{mmol} / \mathrm{l})$ & 4.93 & 5.08 & .15 & 3.0 & $(-3.70,4.50)$ \\
\hline
\end{tabular}


TABLE 4. Correlation Between Changes Among Soluble Factors of Immune System Activation

\begin{tabular}{|c|c|c|c|c|c|c|c|}
\hline \multirow{2}{*}{$\begin{array}{l}\text { Soluble } \\
\text { factors }\end{array}$} & \multicolumn{7}{|c|}{ Soluble factors } \\
\hline & sIL-2R & $\mathrm{B}_{2} \mathrm{M}$ & Neopterin & $\operatorname{IgG}$ & $\operatorname{Ig} \mathrm{A}$ & $\operatorname{IgM}$ & $\operatorname{IgE}$ \\
\hline sIL-2R & & -.005 & .05 & .08 & -.01 & -.06 & .16 \\
\hline $\mathrm{B}_{2} \mathrm{M}$ & & & $.35 * *$ & .13 & .13 & -.04 & .10 \\
\hline Neopterin & & & & .03 & .09 & .03 & .02 \\
\hline $\mathrm{IgG}$ & & & & & $.44 * *$ & .25 & $.16^{*}$ \\
\hline $\operatorname{IgA}$ & & & & & & $.54 * *$ & $.21 * *$ \\
\hline IgM & & & & & & & .01 \\
\hline $\mathrm{IgE}$ & & & & & & & \\
\hline
\end{tabular}

$* P<.001 ; * * P \leq .0001$.

of only two time points for testing. Ideally, several time points spread over a longer interval would provide more information on such issues as seasonal trends and long-term stability of each parameter. However, a major strength of the analysis was the nature of the study population. Subjects were selected as volunteers from a population-based random sample of adults and were carefully screened for health conditions that might influence the tests under study. The population included blacks and whites, men and women over the entire age range from 20 to 69 . In addition, an extensive database of epidemiological information was available on each subject.

In summary, we have analyzed the variability over two time points $\sim 3$ months apart in a number of commonly employed immunologic parameters in a healthy population of adults. Population mean values were quite stable for most measurements, but individual subjects often exhibited substantial variability. Temporal changes in several parameters were significantly correlated. This analysis provides important information for epidemiologists, clinical researchers, and clinicians who must interpret changes in these immunological measurements over time.

\section{REFERENCES}

1. CDC. 1993 Revised classification system for HIV infection and expanded surveillance case definition for AIDS among adolescents and adults. MMWR 41(No. RR-17), 1992.

2. Chess Q, Daniels J, North E, Macris NT. Serum immunoglobulin elevations in the acquired immunodeficiency syndrome (AIDS): IgG, IgA, IgM and IgD. Diagnostic Immunol 2:148-153, 1984.

3. Kramer A, Wiktor SZ, Fuchs D, Milstien S, Gail MH, Yellin FJ, Biggar RJ, et al. Neopterin: A predictive marker of acquired immunodeficiency syndrome in human immunodeficiency virus infection. $J$ Acquir Immune Defic Synd 2:291-296, 1989.
4. Lambin P, Desjobert H, Debbia M, Fine JM, Muller JY. Serum neopterin and $\mathrm{B}_{2}$-microglobulin in anti-HIV positive blood donors. Lancet ii:1216, 1986.

5. Pizzolo G, Vinante F, Morosato L, de Sabata D, Sinicco A, Raiteri R, Agostini C, Semenzato G. Determinants of HIV disease progression. Lancet 339:130, 1992

6. Neopterin and malignant diseases. In Neopterin: Biochemistry-Methods-Clinical Application. H Wachter, D Fuchs, A Hausen, G Reibnegger, G Weiss, ER Werner, G Werner-Felmayer, eds. Walter de Gruyter, Berlin, 1991, p 109-164.

7. Neopterin in autoimmune disorders. In Neopterin: Biochemistry—Methods-Clinical Application. H Wachter, D Fuchs, A Hausen, G Reibnegger, G Weiss, ER Werner, G Werner-Felmayer, eds. Walter de Gruyter, Berlin, 1991, p 77-85, 95-105.

8. Klimas NG, Salvato FR, Morgan R, Fletcher MA. Immunologic abnormalities in chronic fatigue syndrome. J Clin Microbiol 28:1403-1410, 1990.

9. Nishikai M. Chronic fatigue syndrome-study of 51 cases treated at the second Tokyo National Hospital. Nippon Rinsho 50:26252629, 1992.

10. Tollerud DJ, Clark JW, Brown LM, Neuland CY, Pankiw-Trost LK, Blattner WA, Hoover RN. The influence of age, race and gender on peripheral blood mononuclear-cell subsets in healthy nonsmokers.J Clin Immunol 9:214-222, 1989.

11. Tollerud DJ, Clark JW, Brown LM, Neuland CY, Mann DL, PankiwTrost LK, Blattner WA, Hoover RN. The effects of cigarette smoking on T-cell subsets: A population-based survey of healthy caucasians. Am Rev Respir Dis 139:1446-1451, 1989.

12. Tollerud DJ, Clark JW, Brown LM, Neuland CY, Mann DL, PankiwTrost LK, Blattner WA, Hoover RN. Association of cigarette smoking with decreased numbers of circulating natural killer cells. Am Rev Respir Dis 139:194-198, 1989.

13. Diamondstone LS, Tollerud DJ, Fuchs D, Wachter H, Brown LM, Maloney E, Kurman CC, Nelson DL, Blattner WA. Factors influencing serum neopterin and Beta 2-microglobulin levels in a healthy diverse population. J Clin Immunol 14:368-374, 1994.

14. Tollerud DJ, Brown LM, Blattner WA, Weiss ST, Brown LM, Maloney EM, Kurmann CC, Nelson DL, Hoover RN. Racial differences in serum immunoglobulin levels: Relationship to cigarette smoking, T-cell subsets, and soluble interleukin-2 receptors. J Clin Lab Anal 9:37-41, 1995.

15. Tollerud DJ, Kurman CC, Nelson DL, Brown LM, Maloney EM, Blattner WA. Racial variation in serum soluble interleukin-2 receptor levels: A population-based study of healthy smokers and nonsmokers. J Clin Immunol Immunopathol 70:274-279, 1994.

16. Brown LM, Tollerud DJ, Pottern LM, Clark JW, Kase R, Blattner WA, Hoover RN. Biochemical epidemiology in community-based studies: Practical lessons from a study of T-cell subsets. J Clin Epidemiol 42:561568, 1989.

17. Tollerud DJ, Brown LM, Clark JW, Neuland CY, Mann DL, PankiwTrose LK, Blattner WA. Cryopreservation and long term liquid nitrogen storage of peripheral blood mononuclear cells for flow cytometry analysis: Effects on cell subset proportions and fluorescence intensity. $J$ Clin Lab Anal 5:255-61, 1991. 